Keywords: Fuel Cell, PEM, Impurities

Retention: Permanent

\title{
Effect of Fuel Impurities on Fuel Cell Performance and Durability
}

\author{
Hector R. Colon-Mercado
}

September 2010

Savannah River National Laboratory Savannah River Nuclear Solutions, LLC Aiken, SC 29808

Prepared for the U.S. Department of Energy under contract number DE-AC09-08SR22470.

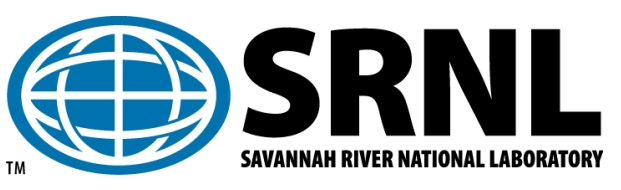


SRNL-STI-2010-00596

Revision 0

\section{DISCLAIMER}

This work was prepared under an agreement with and funded by the U.S. Government. Neither the U.S. Government or its employees, nor any of its contractors, subcontractors or their employees, makes any express or implied:

1. warranty or assumes any legal liability for the accuracy, completeness, or for the use or results of such use of any information, product, or process disclosed; or

2. representation that such use or results of such use would not infringe privately owned rights; or

3. endorsement or recommendation of any specifically identified commercial product, process, or service.

Any views and opinions of authors expressed in this work do not necessarily state or reflect those of the United States Government, or its contractors, or subcontractors.

\section{Printed in the United States of America \\ Prepared for \\ U.S. Department of Energy}




\section{REVIEWS AND APPROVALS}

\section{AUTHORS}

Hector R. Colon-Mercado, Alternative Energy Programs

Date

TECHNICAL REVIEW

Theodore Motyka, Alternative Energy Programs

Date

APPROVAL

Thomas B. Jr Calloway, Manager, Energy Security

Date

Joette G. Sonnenberg, Manager, National Laboratory

Date 


\section{EXECUTIVE SUMMARY}

A fuel cell is an electrochemical energy conversion device that produces electricity during the combination of hydrogen and oxygen to produce water. Proton exchange membranes fuel cells are favored for portable applications as well as stationary ones due to their high power density, low operating temperature, and low corrosion of components. In real life operation, the use of pure fuel and oxidant gases results in an impractical system. A more realistic and cost efficient approach is the use of air as an oxidant gas and hydrogen from hydrogen carriers (i.e., ammonia, hydrocarbons, hydrides). However, trace impurities arising from different hydrogen sources and production increases the degradation of the fuel cell. These impurities include carbon monoxide, ammonia, sulfur, hydrocarbons, and halogen compounds. The International Organization for Standardization (ISO) has set maximum limits for trace impurities in the hydrogen stream; however fuel cell data is needed to validate the assumption that at those levels the impurities will cause no degradation. This report summarizes the effect of selected contaminants tested at SRNL at ISO levels.

Runs at ISO proposed concentration levels show that model hydrocarbon compound such as tetrahydrofuran can cause serious degradation. However, the degradation is only temporary as when the impurity is removed from the hydrogen stream the performance completely recovers. Other molecules at the ISO concentration levels such as ammonia don't show effects on the fuel cell performance. On the other hand carbon monoxide and perchloroethylene shows major degradation and the system can only be recovered by following recovery procedures. 


\section{TABLE OF CONTENTS}

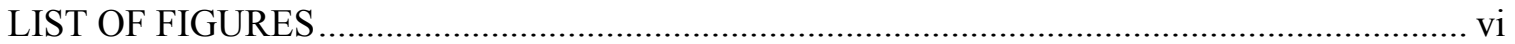

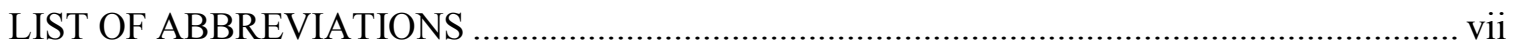

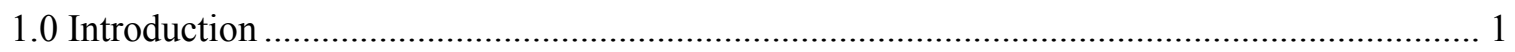

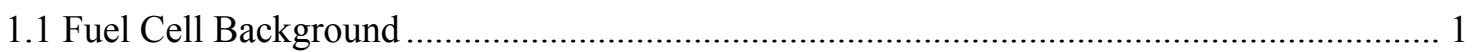

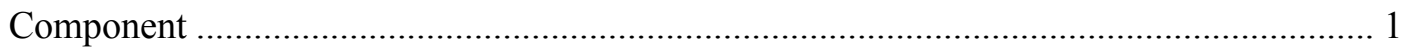

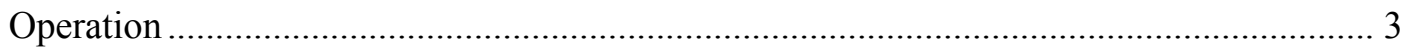

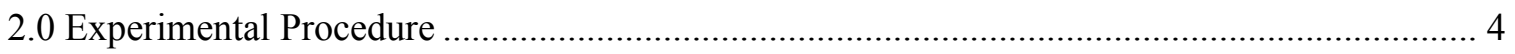

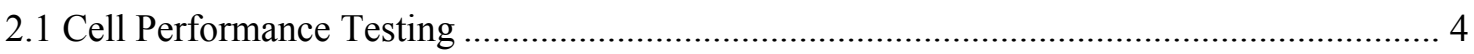

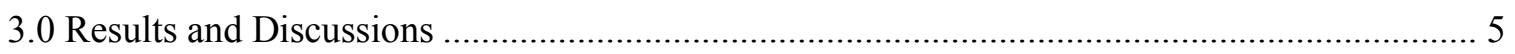

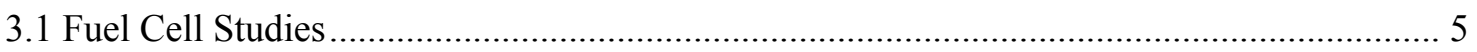

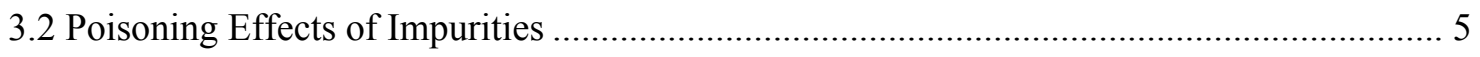

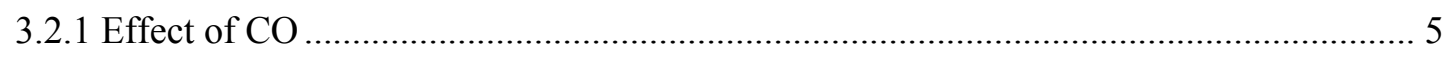

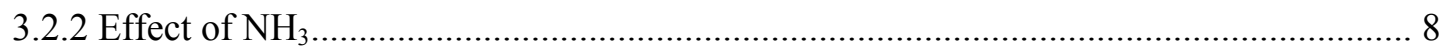

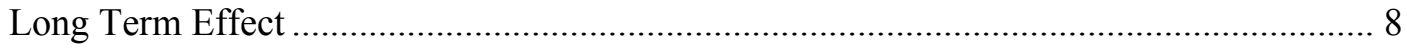

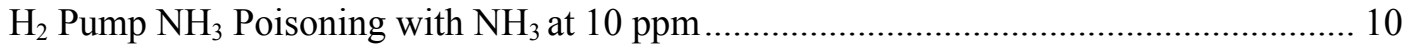

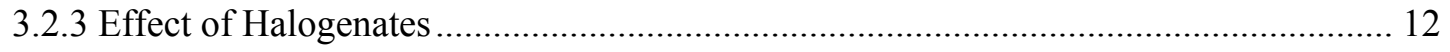

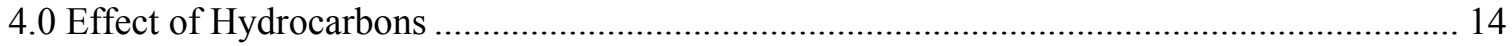

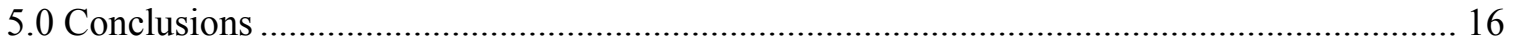

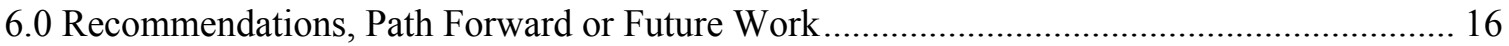

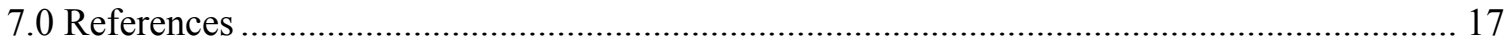




\section{LIST OF FIGURES}

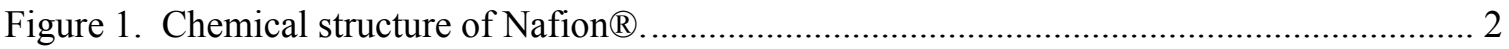

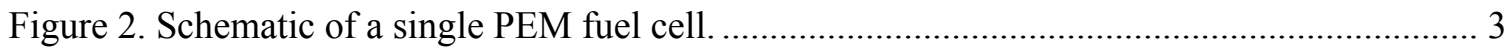

Figure 3. Picture of the KinTek calibration gas generator (left image) that is connected to fuel

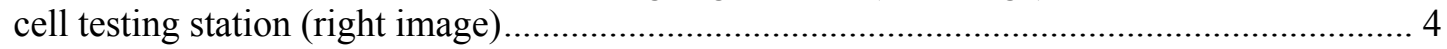

Figure 4. Experimental schematic of the impurity delivery system........................................... 4

Figure 5: Cell performance as a function of relative humidity of an Ion Power MEA at $60^{\circ} \mathrm{C}$ and no impurities.

Figure 6. Current decay during $0.2 \mathrm{ppm}$ CO poisoning of a $50 \mathrm{~cm}^{2}$ Ion Power MEA with an anode Pt loading of $0.1 \mathrm{mg} / \mathrm{cm} 2$ at $60^{\circ} \mathrm{C}$.

Figure 7. Polarization scan before, during and after electrochemical cleaning of the cell during the $0.2 \mathrm{ppm}$ CO poisoning test of a $50 \mathrm{~cm}^{2}$ Ion Power MEA with an anode Pt loading of 0.1 $\mathrm{mg} / \mathrm{cm} 2$ at $60^{\circ} \mathrm{C}$.

Figure 8: $\mathrm{H}_{2} /$ Air potentiostatic polarization baseline for an Ion Power MEA with $0.1 / 0.3 \mathrm{mg} / \mathrm{cm}^{2}$ catalyst loadings at $60^{\circ} \mathrm{C}$ and $50 \% / 50 \% \mathrm{RH}$.

Figure 9: $\mathrm{H}_{2} /$ Air potentiostatic polarization baseline in the presence of $0.1 \mathrm{ppm} \mathrm{NH}_{3}$ for an Ion Power MEA with $0.1 / 0.3 \mathrm{mg} / \mathrm{cm}^{2}$ catalyst loadings at $60^{\circ} \mathrm{C}$ and $50 \% / 50 \% \mathrm{RH}$.................. 10

Figure 10: H2 pump experiment set-up and cycle parameters. ................................................ 11

Figure 11: $\mathrm{H}_{2} / \mathrm{N}_{2}$ galvanostatic polarization in the presence of $10 \mathrm{ppm} \mathrm{NH}_{3}$ for an Ion Power MEA with $0.1 / 0.3 \mathrm{mg} / \mathrm{cm}^{2}$ catalyst loadings at $60^{\circ} \mathrm{C}$ and $100 \% / 50 \% \mathrm{RH}(\mathrm{A} / \mathrm{C}) \ldots \ldots \ldots \ldots \ldots . . . . . .11$

Figure 12: $\mathrm{H}_{2} / \mathrm{N}_{2}$ polarization scan in the presence of $10 \mathrm{ppm} \mathrm{NH}$ for an Ion Power MEA with

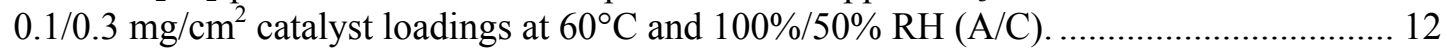

Figure 13. Effect of PCE concentration on PEM fuel cell performance at $60^{\circ} \mathrm{C} \ldots \ldots \ldots \ldots \ldots \ldots \ldots \ldots . . . . . . . .13$

Figure 14. Polarization curves while poisoning with $1 \mathrm{ppm}$ PCE and $0.05 \mathrm{ppm}$ of PCE after steady state saturation has been reached.

Figure 15. Potentiostatic (0.6 V vs. DHE) current decay and recovery during various concentrations of THF in the hydrogen stream in a $50 \mathrm{~cm}^{2}$ Gore MEA with an anode $\mathrm{Pt}$ loading of $0.1 \mathrm{mg} / \mathrm{cm} 2$ at $60{ }^{\circ} \mathrm{C}$ and $50 \% \mathrm{RH}$.

Figure 16. Polarization scan before, during and after recovery of the fuel cell during various concentrations of THF in the hydrogen stream in a $50 \mathrm{~cm}^{2}$ Gore MEA with an anode $\mathrm{Pt}$ loading of $0.1 \mathrm{mg} / \mathrm{cm} 2$ at $60{ }^{\circ} \mathrm{C}$ and $50 \% \mathrm{RH}$. 


\section{LIST OF ABBREVIATIONS}

$\begin{array}{ll}\text { DHE } & \text { Dynamic Hydrogen Electrode } \\ \text { EIS } & \text { Electrochemical Impedance Spectroscopy } \\ \text { GDEs } & \text { Gas Diffusion Electrodes } \\ \text { GDL } & \text { Gas Diffusion Layer } \\ \text { IRAS } & \text { Infrared Reflection Absorption Spectroscopy } \\ \text { ISO } & \text { International Organization for Standardization } \\ \text { MEA } & \text { Membrane Electrode Assembly } \\ \text { PCE } & \text { Perchloroethylene } \\ \text { PEMFC } & \text { Proton Exchange Membrane Fuel Cell } \\ \text { SRNL } & \text { Savannah River National Laboratory } \\ \text { THF } & \text { Tetrahydrofuran }\end{array}$




\subsection{Introduction}

A fuel cell is an electrochemical energy conversion device that produces electricity during the combination of hydrogen and oxygen to produce water. Among the different types of fuel cells, proton exchange membranes fuel cells (PEMFC) are favored for portable applications as well as stationary ones due to their high power density, low operating temperature, and low corrosion of components. ${ }^{1}$ However, commercialization of PEMFC technology requires cost-effective electrocatalysts used in the gas diffusion electrodes (GDEs). Current electrocatalysis for PEMFC research focuses on reducing loading, optimizing reactant diffusivity, ionic and electrical conductivity, and the level of hydrophobicity as well as the resiliency of catalysts. ${ }^{2}$ In spite of numerous attempts to develop a non-Pt catalyst for fuel cell electrodes, platinum supported on high surface area carbon is the most commonly used electrocatalyst for both hydrogen oxidation and oxygen reduction in the PEMFC. Various catalyst layer fabrication approaches such as PEFE-bound, thin-film, vacuum deposition, and electrodeposition methods have been developed. Currently, thin-film methods are widely employed for fabricating catalyst layers for PEMFCs with catalyst loadings less than $0.35 \mathrm{mg} / \mathrm{cm}^{2}{ }^{3}$ In this method, carbonsupported Pt is mixed with Nafion solution and other solvents to form an adequately viscous ink, which is then applied to both sides of a Nafion membrane. Recently, ultra thin catalysts with platinum loadings as low as $0.014 \mathrm{mg} / \mathrm{cm}^{2}$ have been reported using novel sputtering methods. 4

In real life operation, the use of pure fuel and oxidant gases results in an impractical system. A more realistic and cost efficient approach is the use of air as an oxidant gas and hydrogen from hydrogen carriers (i.e., ammonia, hydrocarbons, hydrides). The short and long term effect of impurities in these gases may have an overriding effect on fuel cell performance. Common atmospheric impurities in the cathode gas stream that have an effect on the performance of the fuel cell include sulfur dioxide $\left(\mathrm{SO}_{2}\right)$, nitrogen dioxide $\left(\mathrm{NO}_{2}\right)$, hydrogen sulfide $\left(\mathrm{H}_{2} \mathrm{~S}\right)$, ozone $\left(\mathrm{O}_{3}\right){ }^{6}$ Even though the hydrogen oxidation reaction occurs at higher rates than the oxygen reduction reaction at the cathode, ${ }^{7}$ the effect of hydrogen impurities on fuel cell performance can be devastating. Trace impurities arising from different hydrogen production processes include carbon monoxide, carbon dioxide, ammonia, water, sulfur, hydrocarbons, oxygen, helium, nitrogen, argon, formaldehyde, formic acid and halogenates.

The effects of these different impurities on fuel cell performance remain not fully understood. Trace amounts of impurities can block reaction sites for chemisorption, impede charge transfer, and/or impede proton conduction resulting in a loss in the performance of the fuel cell that can be either permanent or reversible.

\subsection{Fuel Cell Background}

\section{Component}

The electrochemical combination of $\mathrm{H}_{2}$ and $\mathrm{O}_{2}$ occurs at the heart of the fuel cell, commonly called the membrane electrode assembly (MEA). The MEA consists of a proton exchange membrane coated with a catalyst layer on both sides. 
A variety of membrane processes have been explored that may be suitable for application to an extremely acidic environment. During the 1990's and continuing to the present day, there have been numerous publications on membranes for use in fuel cell technology. Specifically, in proton exchange membrane fuel cells, a membrane that is ionically conductive without being overly permeable to water and alcohols has been sought. Current benchmark materials include Nafion-117®, a perfluorosulfonate polymer that has a high degree of ionic conductivity and thermal resistance, (see Figure 1). The proposed physical structure of Nafion polymers has been evolving over the past 25 years and is still a matter of considerable debate today. Initial models were constructed based on small and wide angle X-ray scattering data suggesting that the polymer consists of an array of inverse micelles in which the hydrophobic perfluorinated backbone was phase separated from the hydrophilic sulfonated pendant chains. ${ }^{8,} 9$ Modifications to this model to account for swelling and sorption behavior have been the subject of several review articles. ${ }^{10-12}$ A more current model describes the porous structure of Nafion as consisting of numerous tortuous pathways (pores) ringed on the interior with sulfonate groups, while the bulk material consists of the fluorinated organic. ${ }^{13,14}$ This pore structure is described as being random with numerous twists and dead ends.

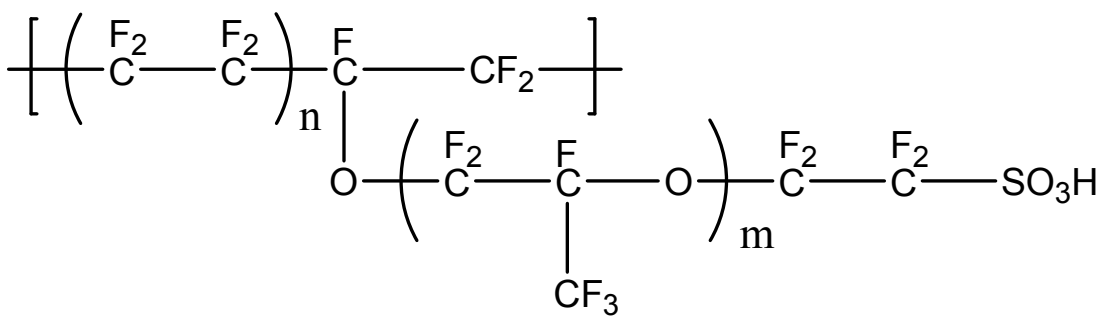

Figure 1. Chemical structure of Nafion ${ }^{\circledR}$.

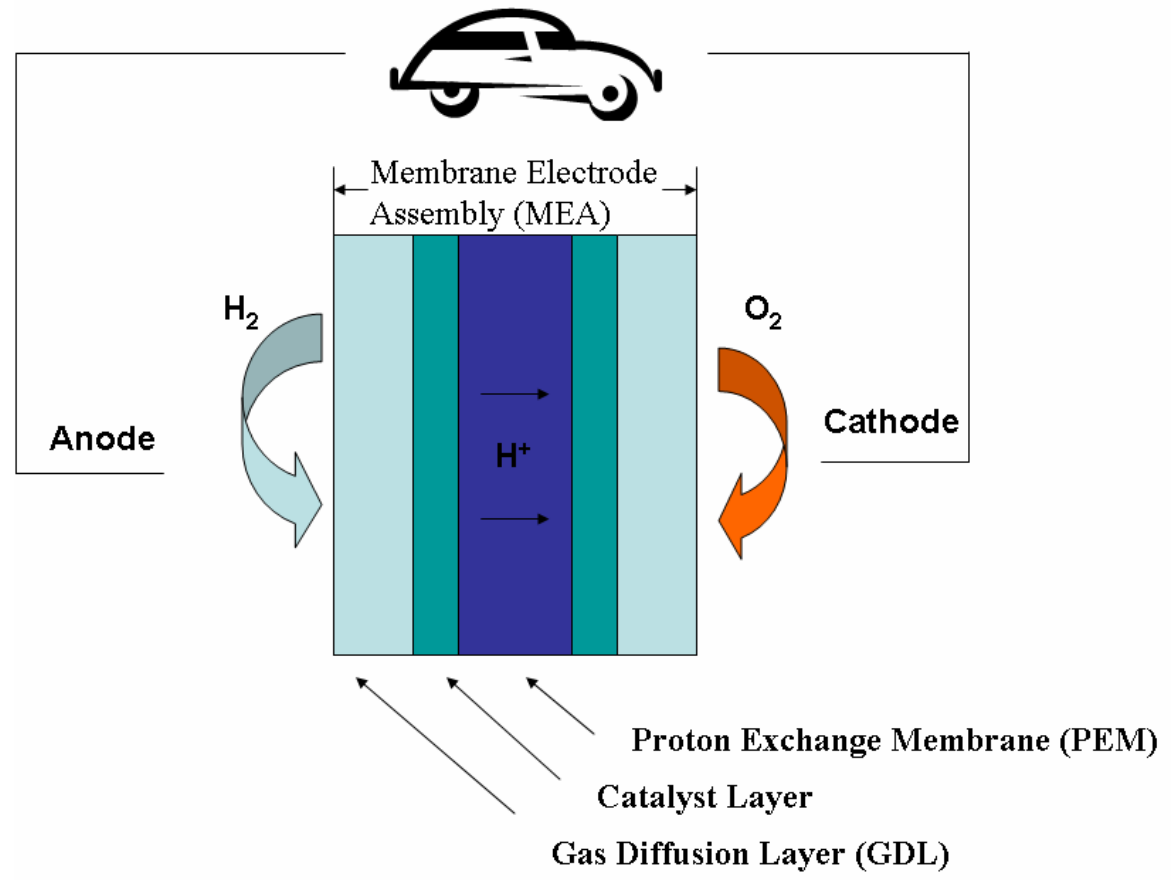


Figure 2. Schematic of a single PEM fuel cell.

Catalyst layers consist of highly dispersed Pt crystallites deposited on high surface area carbon. The anode layer usually contains a Pt-Ru alloy ${ }^{15}$ and the cathode layer contains Pt-transition metal alloys ${ }^{16}$. The electrical contact and gas distribution to the catalyst layers is provided by a wet proofed porous carbon layer supported on a carbon cloth or porous carbon matrix. This layer is often considered part of the MEA and is designated as the gas diffusion layer (GDL). The GDLs are in contact with the flow field plates or bi-polar plates which provide structural integrity to the system, act as current collectors and gas distributors/separators. Figure 2 shows a simplified schematic of the MEA with GDL to form a five-layer sandwich. ${ }^{1}$ Typically, $\mathrm{H}_{2}$ and $\mathrm{O}_{2}$ are delivered to the MEA through two flow field plates that are often mirrored to make a bipolar plate when cells are stacked in series for greater voltages.

\section{Operation}

In a PEMFC, hydrogen is oxidized at the anode and released protons pass through the PEM to the cathode, where oxygen is reduced as indicated below (Eqs. 1-3):

$$
\begin{array}{ll}
\text { Anode: } & \mathrm{H}_{2}-2 \mathrm{e} \rightarrow 2 \mathrm{H}^{+} \\
\text {Cathode: } & 1 / 2 \mathrm{O}_{2}+2 \mathrm{H}^{+}+2 \mathrm{e}^{-} \rightarrow \mathrm{H}_{2} \mathrm{O} \\
\text { Overall: } & \mathrm{H}_{2}+1 / 2 \mathrm{O}_{2} \rightarrow \mathrm{H}_{2} \mathrm{O}
\end{array}
$$

The typical operation temperature for a PEM fuel cell is $70-110^{\circ} \mathrm{C} .{ }^{17}$ The open circuit voltage or theoretical maximum voltage is $1.16 \mathrm{~V} .{ }^{18}$ Useful energy can only be extracted when a practical current is drawn. However, as current is drawn, the system is pushed away from equilibrium resulting in irreversible or polarization losses. Polarization losses can be summarized in three main categories: activation polarization, ohmic polarization, and concentration polarization. The activation polarization is determined by the electrode kinetics. In a fuel cell operating with pure gases, most of the activation polarization arises from sluggish reaction kinetics at the cathode. ${ }^{16}$ The ohmic polarization is determined by the ohmic losses due to the resistance to flow of the protons across the membrane and the resistance to flow of the electrons through the fuel cell components. Finally, the concentration polarization is determined when the catalyst layer is starved of reactants. In the reported work, the effect on the addition of trace impurities on the activation and ohmic losses was studied. 


\subsection{Experimental Procedure}

\subsection{Cell Performance Testing}

Fuel cell performance testing was followed by standard electrochemical measurements such as cyclic-voltametry and electrochemical impedance spectroscopy techniques using commercially available fuel cell test stations and MEA. Figure 3 (right image) shows the enclosure containing the environmental chambers that were used to set temperature and humidity conditions for the fuel cell. Gas pressures and gas mixtures were set using manometric gas manifolds and analytical spectroscopic techniques. Figure 3 (left image) shows the module providing the impurities to the fuel cell station. Impurities were provided by a $\operatorname{KinTek}{ }^{\circledR}$ calibration gas generator. Figure 4 shows the experimental schematic of how the two systems were synchronized so that automated continuous operations were achieved.
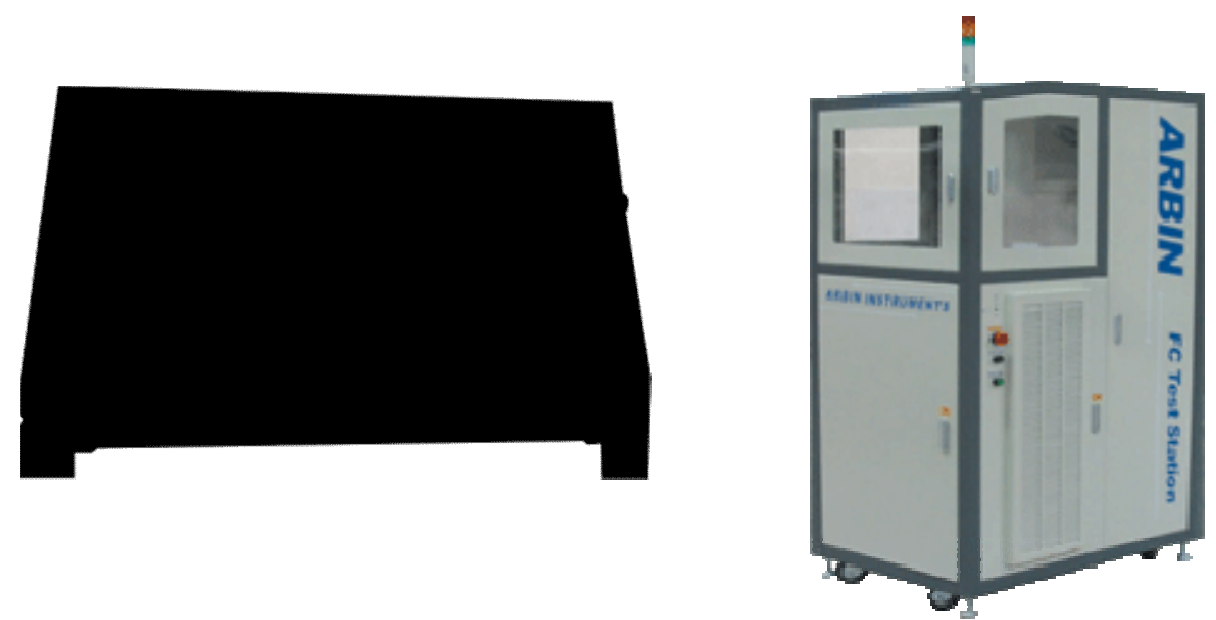

Figure 3. Picture of the KinTek calibration gas generator (left image) that is connected to fuel cell testing station (right image)

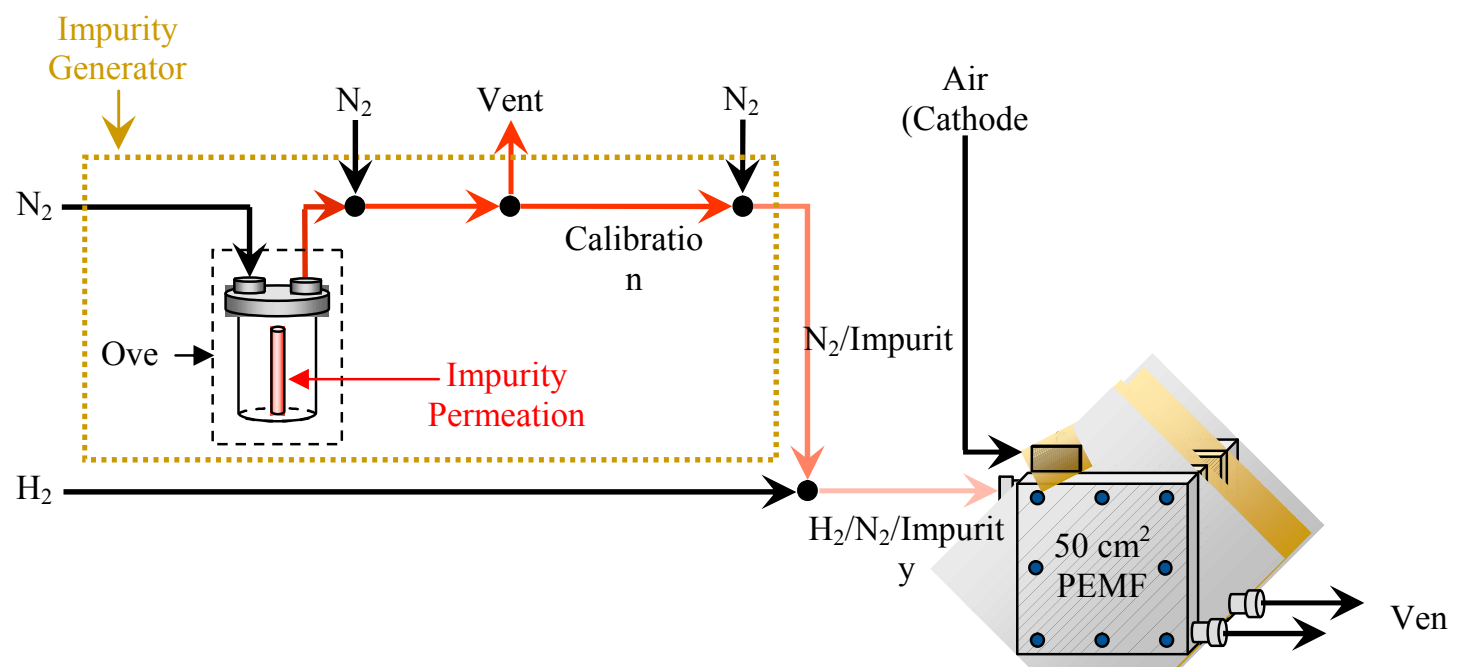

Figure 4. Experimental schematic of the impurity delivery system. 
SRNL-STI-

Revision 0

\subsection{Results and Discussions}

\subsection{Fuel Cell Studies}

A commercially-available MEA (Ion Power), $50 \mathrm{~cm}^{2}$ active area with a total of $0.1 \mathrm{mg}$ of Pt catalyst on the anode and $0.3 \mathrm{mg}$ of $\mathrm{Pt}$ on the cathode, was tested at $60^{\circ} \mathrm{C}$ in neat hydrogen and no back-pressure. The test sought to establish the baseline performance at different relative humidities. The selected conditions are believed to be representative of 2 major conditions which includes "dry" operations (automotive conditions, $50 \% \mathrm{RH} / 50 \% \mathrm{RH}$ ) and "wet" operation (normal laboratory conditions, 100\% $\mathrm{RH} / 100 \% \mathrm{RH})$. The third case study was a combination of the first two cases, where the anode is run "wet" $(100 \% \mathrm{RH})$ and the cathode is run "dry" $(50 \% \mathrm{RH})$. Figure 5 shows the performance results for the three different case studies. As can be observed from the figure, the performance decreases as the relative humidity decreased. The effect was more pronounced at the intermediate current densities (between 0.2 to $1.0 \mathrm{~A} / \mathrm{cm}^{2}$ ), where the limitations of the cells are dominated by the membrane resistance.

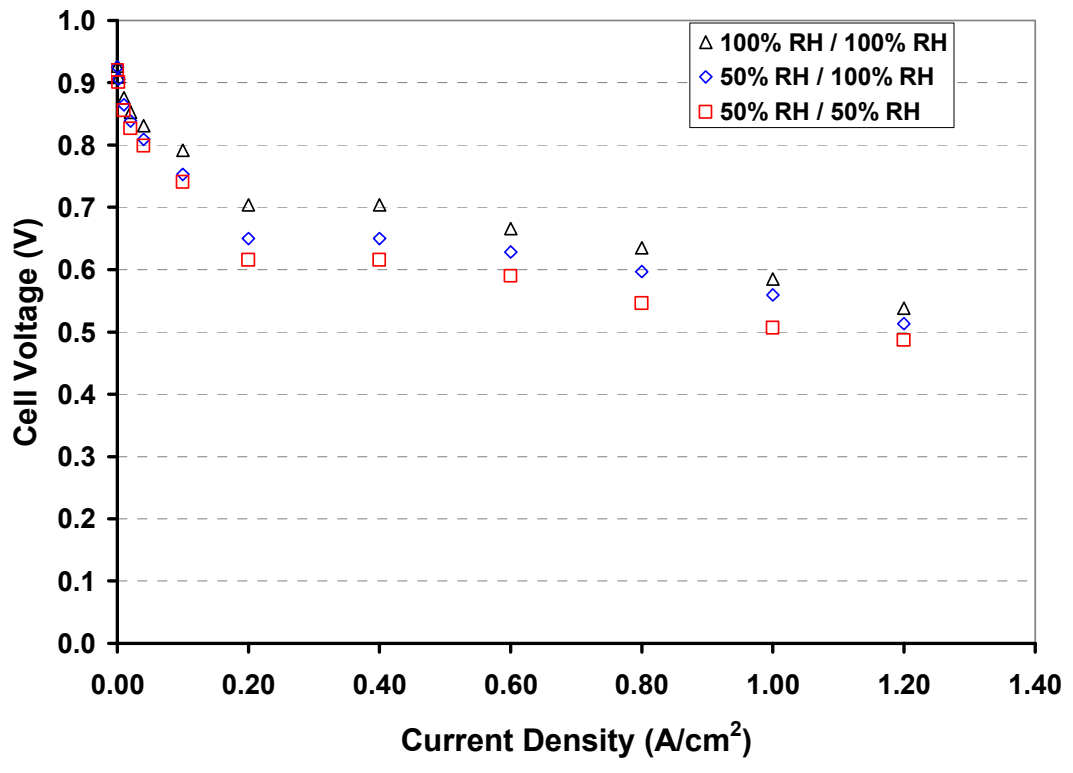

Figure 5: Cell performance as a function of relative humidity of an Ion Power MEA at $60^{\circ} \mathrm{C}$ and no impurities.

\subsection{Poisoning Effects of Impurities}

\subsubsection{Effect of $C O$}

Poisoning of PEMFCs associated with $\mathrm{CO}$ has been most extensively studied due to the fact that $\mathrm{CO}$ is present in $\mathrm{H}_{2}$-rich fuel gases generated by reforming and /or partial oxidation of various hydrocarbons, in particular of natural gas, gasoline, methanol or higher alcohols. ${ }^{19}$ Gottesfeld and Pafford reported the earliest work on $\mathrm{CO}$ poisoning of fuel cells in $1988 .^{20}$ They recorded the poisoning phenomenon with CO levels varying from 10 to $100 \mathrm{ppm}$. Later, the same research group developed a kinetic model for 
hydrogen and $\mathrm{CO}$ adsorption and subsequent electro-oxidation. ${ }^{21}$ It was concluded that in the presence of $\mathrm{CO}$ levels as low as $10 \mathrm{ppm}$, the performance loss starts to become significant. This model has been extended and modified several times by other researchers. ${ }^{22-24}$ Meanwhile, the transient process of poisoning in a hydrogen/oxygen fuel cell has also been experimentally studied using cell polarization measurements. ${ }^{25-27}$ Wang et. al. ${ }^{25}$ confirmed that hydrogen dilution amplifies the $\mathrm{CO}$ poisoning. Oetjen et. al. ${ }^{26}$ observed Pt catalyst performance degradation even after 5 min of exposure to a feed consist of $100 \%$ hydrogen with $100 \mathrm{ppm}$ CO. Murthy et al. ${ }^{27}$ found that a small amount of air injection into the anode feed can reduce the transient decay rate of fuel cell polarization during the $\mathrm{CO}$ poisoning process.

Aside from cell polarization measurements, researchers have been applying other methods to study the $\mathrm{CO}$ poisoning process on Pt-based catalysts. Wagner and Gulzow studied the change in electrochemical impedance spectra (EIS) with time during CO poisoning of the $\mathrm{Pt} / \mathrm{C}$ anode in a membrane fuel cell. ${ }^{28}$ Markovic et al. employed infrared reflection absorption spectroscopy (IRAS) to study the vibrational properties of $\mathrm{CO}$ at the $\mathrm{Pt}(111)$-solution interface. ${ }^{29}$ This research group also applied IRAS to study the oxidation of $\mathrm{CO}$ on platinum nanoparticles ranging in size from 1 to $30 \mathrm{~nm}^{30,31}$ Davies et al. determined $\mathrm{CO}$ adsorption rates over platinum fuel cell catalysts through isotopic exchange experiments. They also applied High Pressure Scanning Tunneling Microscopy to study the pressure dependency of the coverage. ${ }^{32}$ Villegas and Weaver studied the spatial structure of compressed carbon monoxide ad layers on $\operatorname{Pt}(111)$ in aqueous acidic electrolyte by means of in-situ scanning tunneling microscopy along with infrared reflection-absorption spectroscopy (IRAS). ${ }^{33}$ Markovic et al. ${ }^{34}$ examined the $\operatorname{Pt}(100)-\mathrm{CO}$ interaction in aqueous electrolytes using in-situ surface X-ray scattering measurements and found that the topmost platinum atoms expand away from the second layer by ca. $4 \%$ when the hydrogen under-potential deposition $\left(\mathrm{H}_{\text {upd }}\right)$ was completely displaced from $\mathrm{Pt}(100)$ by $\mathrm{CO}$ to form a saturated layer of $\mathrm{CO}$. Solid state NMR spectroscopic methods have also been used to investigate fuel cell related electrocatalytic systems. ${ }^{35-38}$ These studies employed ${ }^{13} \mathrm{C}$ or/and ${ }^{195} \mathrm{Pt}-\mathrm{NMR}$ to study the effect of poisoning by $\mathrm{CO}$ of the $\mathrm{Pt}$ surface at molecular level.

The mechanism by which a Pt catalyst is poisoned by $\mathrm{CO}$ has also been a subject of much discussion. One explanation is that $\mathrm{CO}$ blocks or limits the active sites of the platinum catalyst due to adsorption which leads to an inhibition of hydrogen adsorption and oxidation as shown below (Eqs. 4-6), ${ }^{39-43}$

$$
\begin{aligned}
& \mathrm{H}_{2}+2 \mathrm{Pt} \rightarrow 2(\mathrm{H} / \mathrm{Pt}) \\
& 2(\mathrm{H} / \mathrm{Pt}) \rightarrow 2 \mathrm{H}^{+}+2 \mathrm{e}^{-}+2 \mathrm{Pt} \\
& \mathrm{CO}+\mathrm{Pt} \rightarrow \mathrm{CO} / \mathrm{Pt}
\end{aligned}
$$

It was found that $\mathrm{CO}$ could block $98 \%$ of the active sites of Pt catalyst at $25^{\circ} \mathrm{C}$ for a $1 \%$ $\mathrm{CO} /$ hydrogen mixture as feed fuel. ${ }^{44}$ Thus, it's not surprising that compared with the use of pure hydrogen, the maximum power density is halved in the presence of only $5 \mathrm{ppm}$ carbon monoxide. ${ }^{45}$

Use of CO-tolerant catalysts is generally considered the most promising way for solving the $\mathrm{CO}$ poisoning problem in PEMFCs since it causes less associated problems compared to other solutions such as bleeding oxidant into the fuel feed. ${ }^{46-48}$ Use of binary 
systems of electrocatalysts in the form of alloys containing Pt and a second metal such as $\mathrm{Ru}, \mathrm{Sn}, \mathrm{Co}, \mathrm{Cr}, \mathrm{Fe}, \mathrm{Ni}, \mathrm{Pd}, \mathrm{Os}, \mathrm{Mo}, \mathrm{Mn}$, etc. results in a significant improvement in $\mathrm{CO}$ tolerance. $^{49-56}$ However, a substantial loss in cell potential is usually observed for fuel cells using these binary catalysts. ${ }^{57,58}$ Thus, overcoming $\mathrm{CO}$ poisoning of $\mathrm{Pt}$ catalysts in PEMFCs still remains a challenge.

$\mathrm{CO}$ poisoning experiments were performed to study the performance decay at International Office for Standardization (ISO) limits. Figure 6 shows the current decay at $0.6 \mathrm{~V}$ with time during the poisoning. The potentiostatic curve has been corrected for the typical degradation of the MEA observed before the poisoning. Notice that after $40 \mathrm{hrs}$ the decay rate decreased indicating a steady state was reached. Although the concentration of $\mathrm{CO}$ is small, the performance decayed almost $10 \%$ in a few hours. This decay is significant as it will immediately reduce the performance of the system by close to $10 \%$ at the beginning of life. With other factors to consider such as other impurities and components degradation, the effects of CO at ISO limits are appreciable.

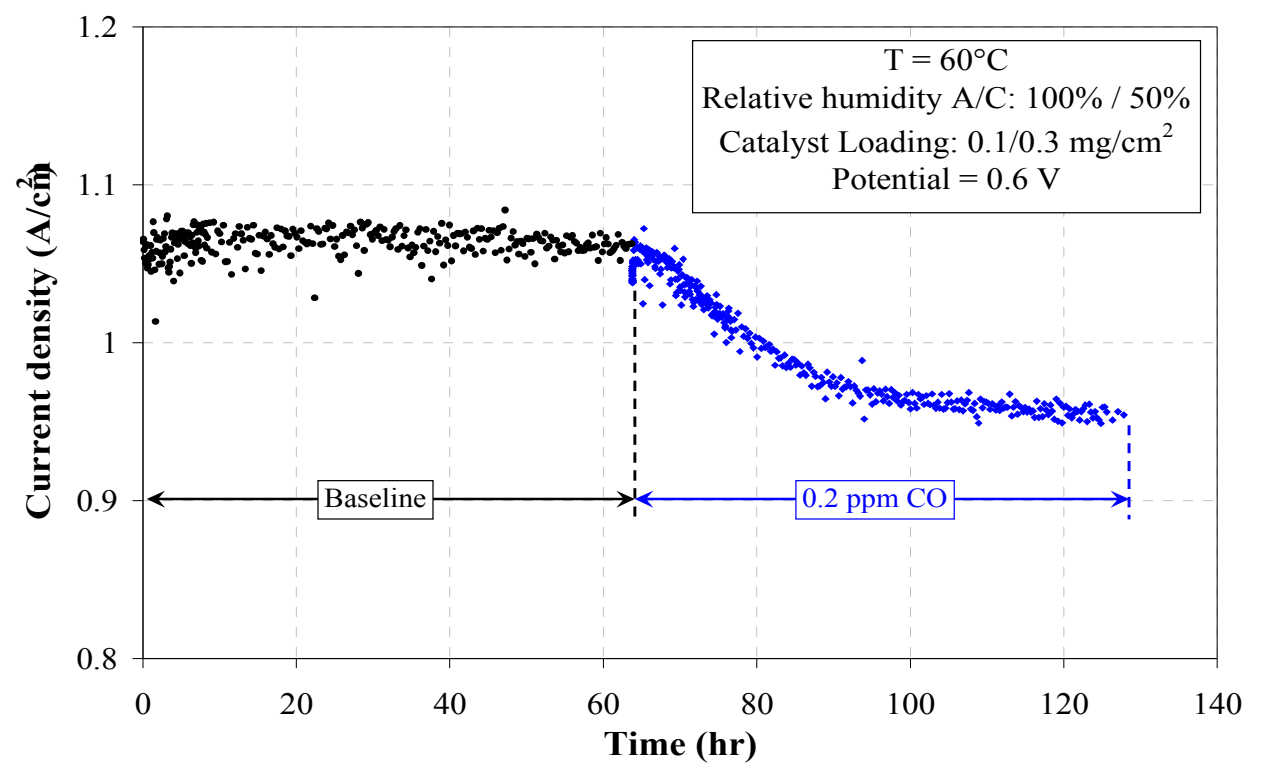

Figure 6. Current decay during $0.2 \mathrm{ppm}$ CO poisoning of a $50 \mathrm{~cm}^{2}$ Ion Power MEA with an anode $P t$ loading of $0.1 \mathrm{mg} / \mathrm{cm} 2$ at $60^{\circ} \mathrm{C}$.

Figure 7 shows the polarization scan before and during exposure of $\mathrm{CO}$, and after electrochemical oxidation of $\mathrm{CO}$ through cyclic voltammetry. As expected, electrochemical oxidation successfully removes all traces of $\mathrm{CO}$ and the MEA performance is recovered. 


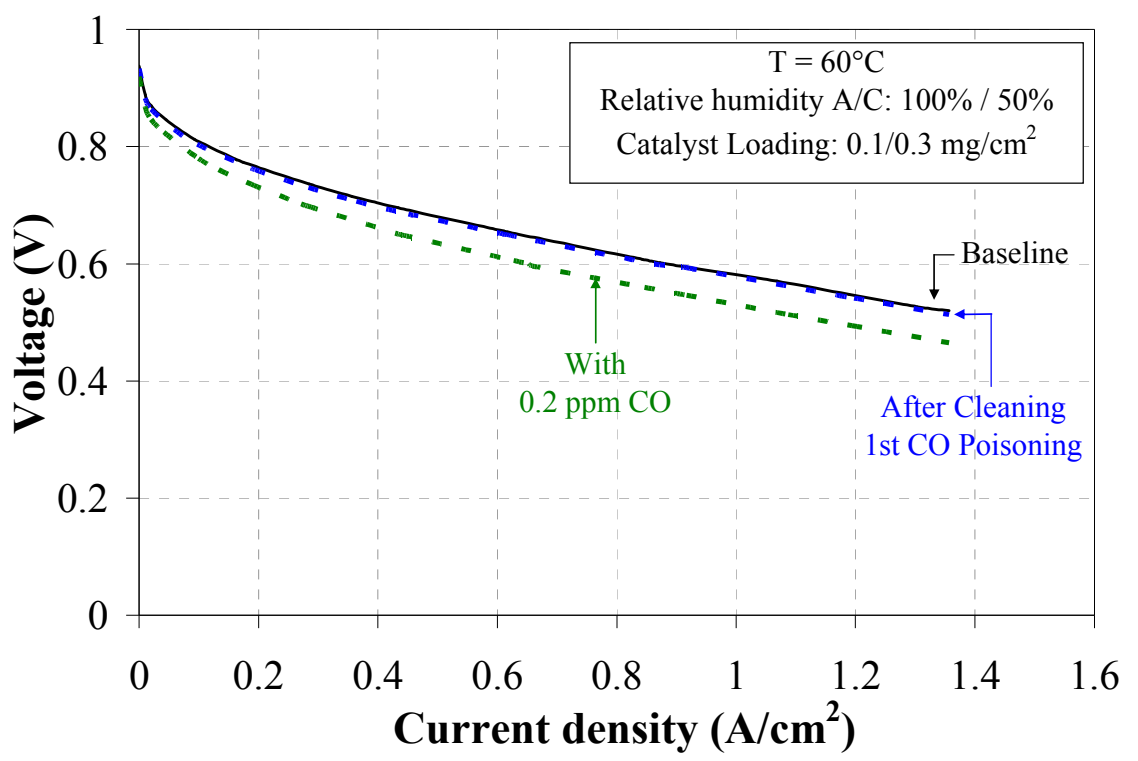

Figure 7. Polarization scan before, during and after electrochemical cleaning of the cell during the $0.2 \mathrm{ppm} C O$ poisoning test of a $50 \mathrm{~cm}^{2}$ Ion Power MEA with an anode Pt loading of $0.1 \mathrm{mg} / \mathrm{cm} 2$ at $60^{\circ} \mathrm{C}$.

\subsubsection{Effect of $\mathrm{NH}_{3}$}

\section{Long Term Effect}

Although interaction of $\mathrm{NH}_{3}$ with Pt surfaces has been studied for years because platinum is an excellent catalyst for ammonia oxidation, ${ }^{59-66}$ not much work has been carried out regarding ammonia contamination of Pt catalysts in PEMFCs. It is known, however, that trace ammonia present in hydrogen rich fuel streams degrades cell performances. ${ }^{67}$ The early study indicated that the platinum catalyst surface (anode) was not directly poisoned by ammonia, but that the decrease in fuel cell performance was caused by the replacement of $\mathrm{H}^{+}$ions by $\mathrm{NH}_{4}{ }^{+}$ions within the anode catalyst layer and also by the decrease in the conductivity of the membrane.

Using MEAs containing 0.15-0.20 $\mathrm{mg} \mathrm{Pt} \mathrm{cm}^{-2}$ catalyst on both electrodes, Uribe et al. ${ }^{68}$ studied poisoning of PEMFC during the exposure to ammonia and found that the cell resistance more than doubled when the cell was exposed to $30 \mathrm{ppm}$ ammonia for 15 hours. The cell resistance started to increase after being exposed to ammonia for more than 1 hour and was not fully recoverable within 4 days of operation if the exposure time exceeded 17 hours.

Soto et al. ${ }^{69}$ monitored the cell resistance of a GORE ${ }^{\mathrm{TM}}$ PRIMEA series 5621 MEA with a Pt/Ru anode catalyst and a Pt cathode catalyst. They observed much less increase in cell resistance than that observed by Uribe et al. ${ }^{68}$ who used a lower concentration of ammonia. Uribe et al. ${ }^{68}$ and Soto et al. ${ }^{69}$ all suggested that ammonia interfered primarily with the anode. However, no detailed hypothesis concerning the poisoning mechanism was proposed. 
Recently, Halseid et al. ${ }^{70}$ examined the effect of ammonia on PEMFCs more systematically. They concluded that poisoning of PEMFCs by ammonia is severe even for concentrations of $1 \mathrm{ppm} \mathrm{NH}$. The performance loss of the fuel cell was in most cases reversible, but only after operation on neat hydrogen for several days. These results indicate that more work, both experimental and modeling, is needed to understand the different poisoning mechanisms of PEMFCs induced by ammonia.

Experiments were conducted to understand the impact of $\mathrm{NH}_{3}$ on the fuel cell at the ISO fuel quality limit. A baseline and $0.1 \mathrm{ppm}$ poisoning at $60^{\circ} \mathrm{C}$ and $50 / 50 \% \mathrm{RH}$ with an Ion Power MEA to determine the impact of $\mathrm{NH}_{3}$ at the ISO limit were performed.

Figure 8 and Figure 9 show the potentiostatic polarization for the baseline cell (under neat $\mathrm{H}_{2}$ ) and the cell tested with a $\mathrm{H}_{2}$ stream containing $0.1 \mathrm{ppm}$ of $\mathrm{NH}_{3}$, respectively. As the figures show, both the cells with and without ammonia show a degradation rate of 15 $\mathrm{mA} / \mathrm{hr}$. This preliminary result indicates no appreciable degradation from the introduction of $\mathrm{NH}_{3}$ at ISO specified level.

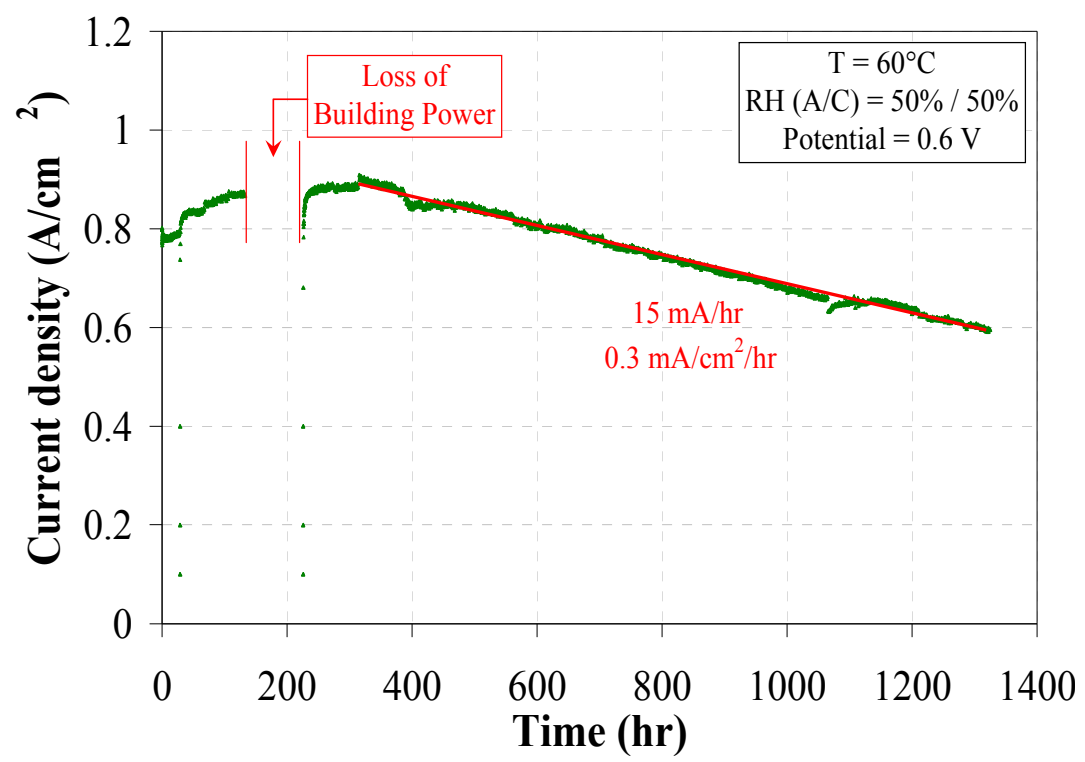

Figure 8: $\mathrm{H}_{2}$ /Air potentiostatic polarization baseline for an Ion Power MEA with $0.1 / 0.3 \mathrm{mg} / \mathrm{cm}^{2}$ catalyst loadings at $60^{\circ} \mathrm{C}$ and $50 \% / 50 \% \mathrm{RH}$. 


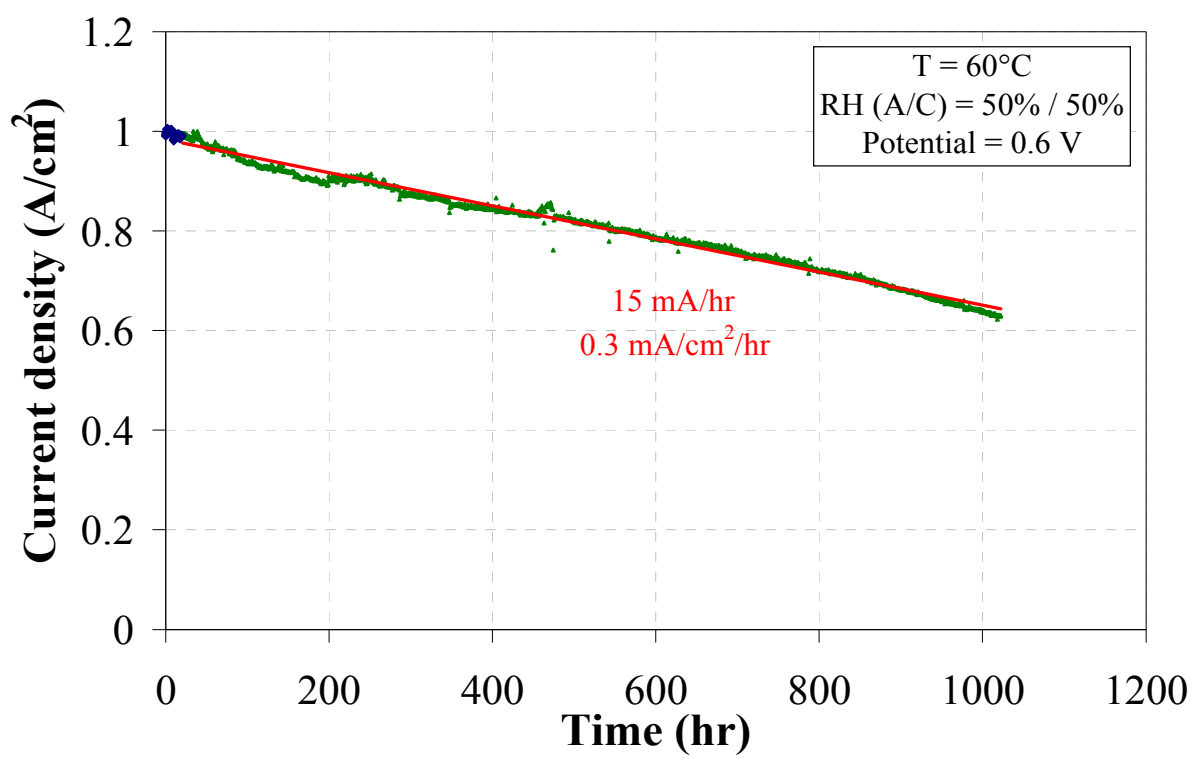

Figure 9: $\mathrm{H}_{2}$ /Air potentiostatic polarization baseline in the presence of $0.1 \mathrm{ppm} \mathrm{NH}_{3}$ for an Ion Power MEA with $0.1 / 0.3 \mathrm{mg} / \mathrm{cm}^{2}$ catalyst loadings at $60^{\circ} \mathrm{C}$ and $50 \% / 50 \%$ RH.

\section{$\underline{\mathrm{H}}_{2}$ Pump $\mathrm{NH}_{3} \underline{\text { Poisoning with } \mathrm{NH}_{3} \text { at } 10 \mathrm{ppm}}$}

A hydrogen pump experiment was used to characterize changes in MEA properties during $\mathrm{NH}_{3}$ poisoning. By performing the $\mathrm{H}_{2}$ pump on a $\mathrm{H}_{2} / \mathrm{N}_{2}$ system that is being poisoned at a current similar to an operating fuel cell, the kinetics of $\mathrm{NH}_{3}$ poisoning of the membrane and ionomer can be measured. Figure 10 shows the experimental set up and the experiment cycle parameters. In a typical cycle, hydrogen will flow to the anode and nitrogen to the cathode. Then a current will be applied in order to oxidize the $\mathrm{H}_{2}$ at the anode and reduce it at the cathode, just like in a typical fuel cell run. However, the oxygen reaction will be avoided thus measuring the effects of only the ammonia on the hydrogen redox reaction. During an experiment, the cell will be polarized by applying 50 A $\left(1 \mathrm{~A} / \mathrm{cm}^{2}\right)$ for 26 minutes, then a polarization will be measured by scanning between 0.2 and $1.4 \mathrm{~A} / \mathrm{cm}^{2}$. The experiment is then cycled until steady state conditions are reached. 

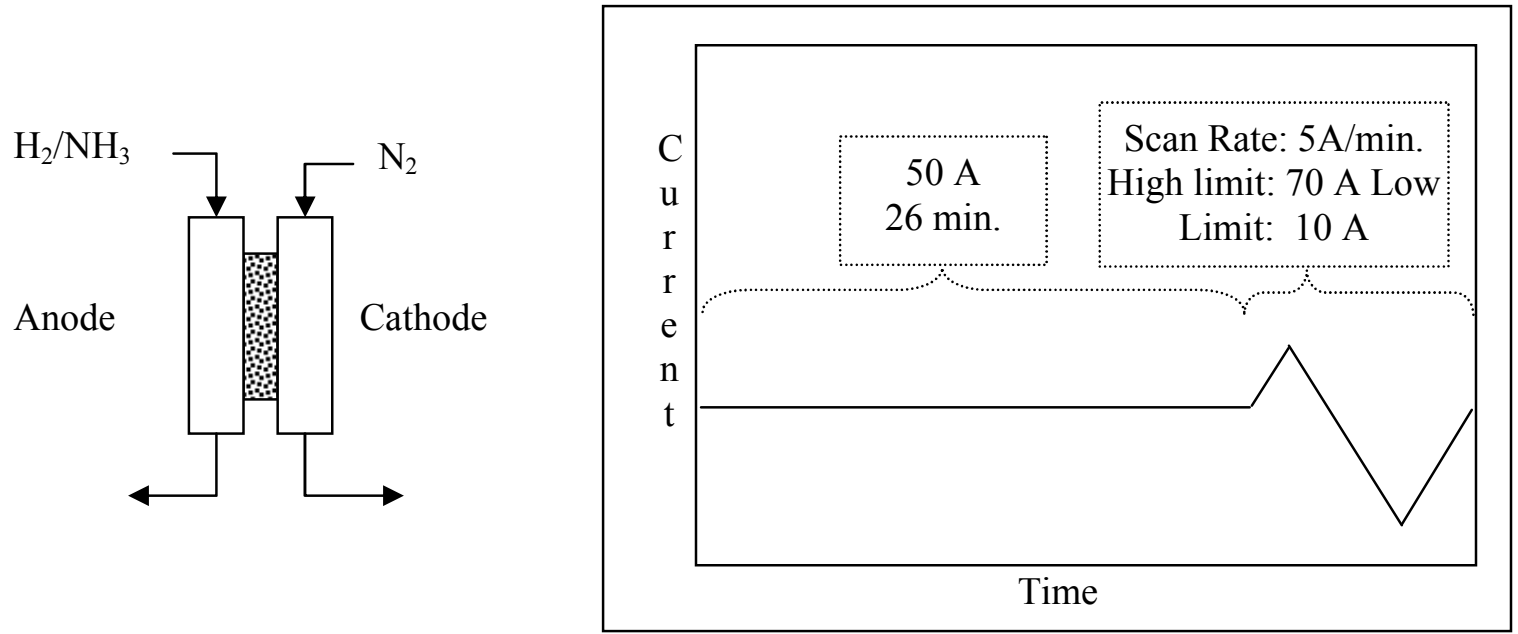

Figure 10: H2 pump experiment set-up and cycle parameters.

Figure 11 shows the results of the $1 \mathrm{~A} / \mathrm{cm}^{2}$ section of the cycle. During the first 17 hours the cell ran with neat $\mathrm{H}_{2}$, after that $10 \mathrm{ppm}$ of $\mathrm{NH}_{3}$ was injected along the hydrogen stream. As it can be seen in the figure, the introduction of $\mathrm{NH}_{3}$ increases the overpotential of the $\mathrm{H}_{2}$ oxidation reaction about $500 \mathrm{mV}$. The system quickly reaches steady state in about 12 hours from the start of the poison.

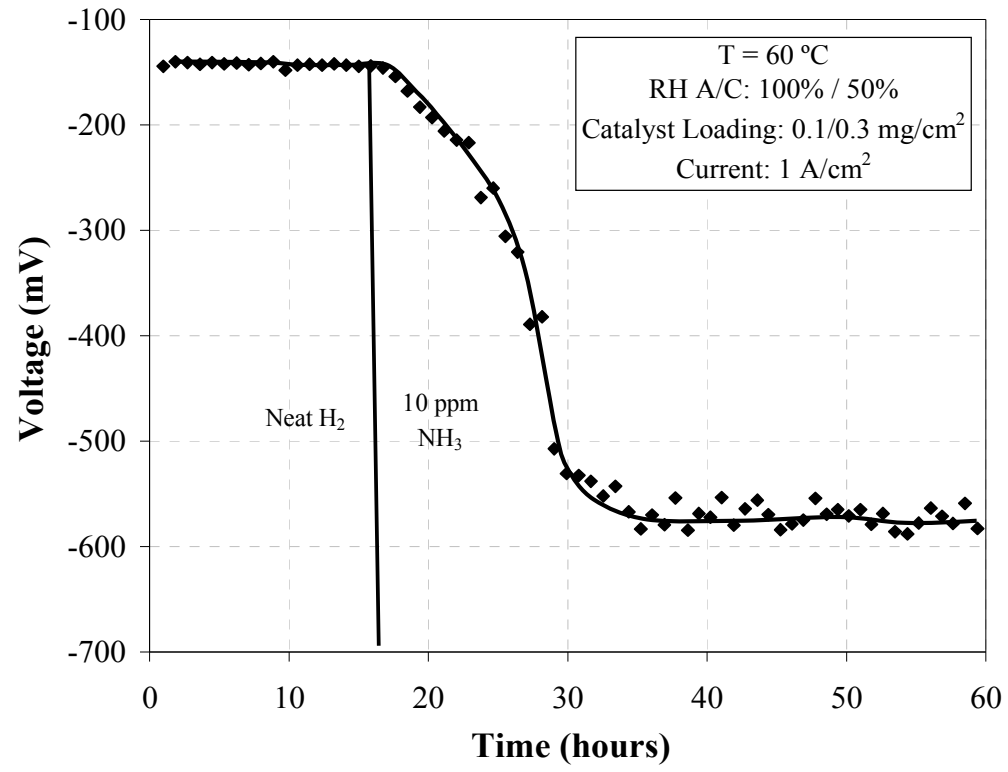

Figure 11: $\mathrm{H}_{2} / \mathrm{N}_{2}$ galvanostatic polarization in the presence of $10 \mathrm{ppm} \mathrm{NH}_{3}$ for an Ion Power MEA with $0.1 / 0.3 \mathrm{mg} / \mathrm{cm}^{2}$ catalyst loadings at $60^{\circ} \mathrm{C}$ and $100 \% / 50 \% \mathrm{RH}$ $(\mathrm{A} / \mathrm{C})$.

Figure 12 shows some of the results from the polarization scan. From the experiment the slope of the curve can be related to the resistance of the cell. When neat $\mathrm{H}_{2}$ flows in to the cell, a straight line is observed. As soon as $\mathrm{NH}_{3}$ is introduced, the slope of the line starts to increase and it was noted that the line starts to develop an 
inflection point and two slopes are observed. At current densities below around 0.75 $\mathrm{A} / \mathrm{cm}^{2}$ the rate of change of the slope tends to be slower than the rate of change of the slope at current densities higher than $0.75 \mathrm{~A} / \mathrm{cm}^{2}$. This difference in slope can be an indication of the effect of the $\mathrm{NH}_{3}$ on the conductivity of the different regions inside the MEA.

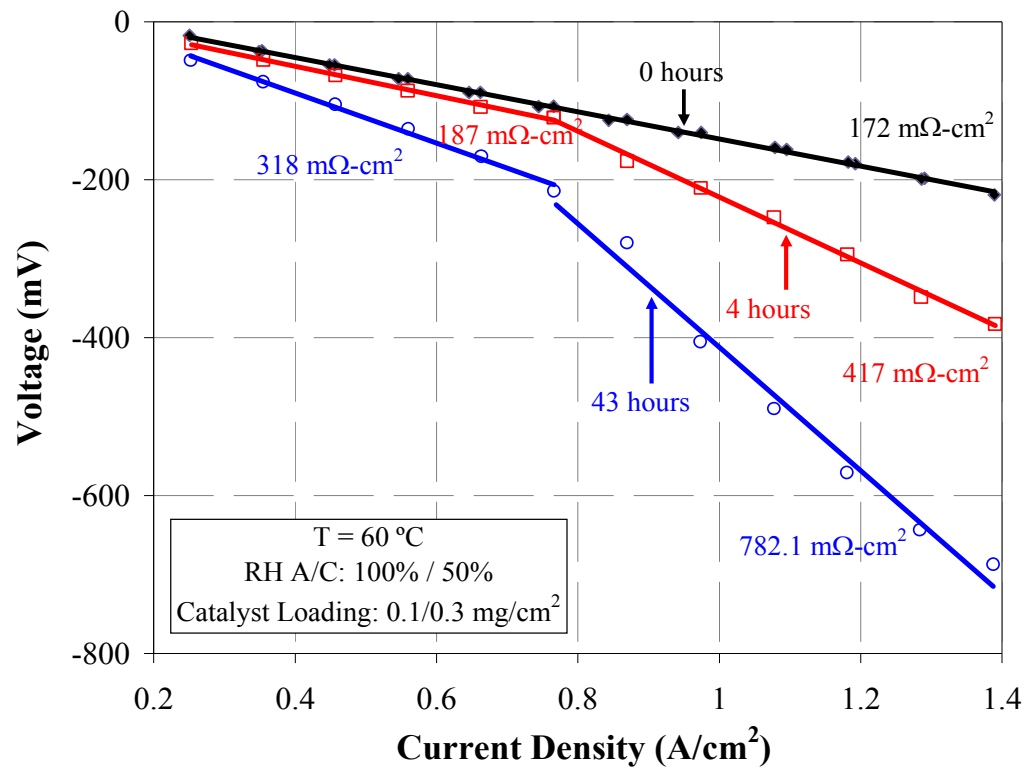

Figure 12: $\mathrm{H}_{2} / \mathrm{N}_{2}$ polarization scan in the presence of $10 \mathrm{ppm} \mathrm{NH}_{3}$ for an Ion Power MEA with $0.1 / 0.3 \mathrm{mg} / \mathrm{cm}^{2}$ catalyst loadings at $60^{\circ} \mathrm{C}$ and $100 \% / 50 \% \mathrm{RH}(\mathrm{A} / \mathrm{C})$.

\subsubsection{Effect of Halogenates}

Little work has been carried out studying influence of halogenates on the performance of electrocatalysts of PEMFCs. It is known that aqueous chloride ions accelerate the corrosion of all metals. Wagner and Moylan ${ }^{71}$ studied the adsorption of anhydrous $\mathrm{HCl}$ on $\mathrm{Pt}(111)$ at $90 \mathrm{~K}$ and its coadsorption with hydrogen and water using high resolution electron energy loss spectroscopy, temperature programmed desorption (TPD), low energy electron diffraction, and Auger electron spectroscopy. They concluded that, at low coverages, $\mathrm{HCl}$ fully dissociated to form a disordered mixture of adsorbed $\mathrm{H}$ and $\mathrm{Cl}$ atoms. For higher exposures (and coverages) first a well-ordered $3 \mathrm{x}$ 3 phase was produced and then an increasingly disordered form which reached saturation just above the density of one layer of close-packed $\mathrm{Cl}$.

Kashima et al. ${ }^{72}$ studied the influence of $\mathrm{Cl}^{-}$ion addition on methanol electrooxidation on a Nafion-modified $\mathrm{Pt}$ microelectrode and found that $\mathrm{Cl}^{-}$ion adsorbs on the $\mathrm{Pt}$ surface, which prohibited not only $\mathrm{Pt}$ oxide formation but also $\mathrm{MeOH}$ electrooxidation.

Conway et al. ${ }^{73-76}$ studied the competitive adsorption of $\mathrm{Cl}^{-}, \mathrm{Br}^{-}$and $\mathrm{I}^{-}$over a wide range of concentrations, $\leq 10^{-6}$ to $10^{-3}-10^{-2} \mathrm{M}$ through anodic oxide formation on $\mathrm{Pt}$ by means of cyclic voltammetry and adsorption isotherms. They discovered that the presence of these halide anions causes the lowering of double-layer capacitance behavior of polycrystalline Pt electrodes. 
Strmcnik et al. ${ }^{77}$ investigated the effect of halide ions and Nafion on CO electrooxidation. They found that the formation of oxide species was obstructed by halide ions, causing the $\mathrm{CO}$ oxidation peak to move to more positive potentials. Iodine had the largest effect, followed by bromide, chloride and fluoride, which can be explained by the same order for adsorption affinity of halide ions on platinum.

Pt-sensor electrodes have been used to detect organic halides with sensitivities in the low-ppm range taking advantage of the adsorption of these compounds on $\mathrm{Pt}^{78-79}$ which indicates the potential poisoning by organic halides in fuel cells as a result of occupying active catalyst sites.

Impurity tests were performed with perchloroethylene (PCE) to characterize the performance effects that chlorinated cleaning agents can have on fuel cell performance. PCE concentrations of $30 \mathrm{ppm}, 1 \mathrm{ppm}$, and $0.05 \mathrm{ppm}$ were tested with anode/cathode relative humidities of $100 \% / 50 \% \mathrm{RH}$. The $50 \mathrm{ppb}$ concentration is the ISO total limit for halogenated compounds in the hydrogen stream. The current decay curves during the duplicate experiments are shown in Figure 13. SRNL will be working with hydrogen producers to identify other halogenated compounds such as heat transfer fluids that should be studied as part of the evaluation of halogenated compounds for the ISO standard. It is likely that other chlorinated alkenes such as trichloroethylene, dichloroethylene, and chloroethylene would also need to have a reduced fuel quality limit. Future testing in this area will investigate the most relevant halogenated hydrocarbons as suggested by industry and the DOE.

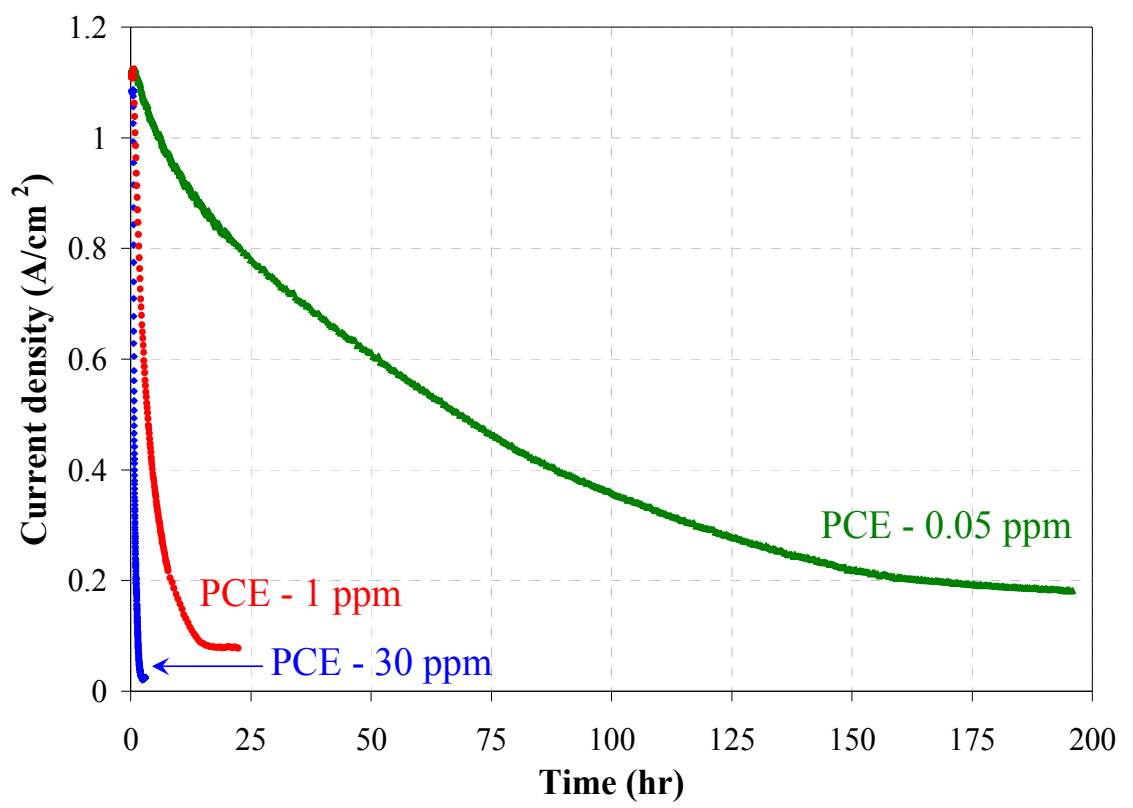

Figure 13. Effect of PCE concentration on PEM fuel cell performance at $60^{\circ} \mathrm{C}$.

After poisoning the fuel cell, polarization curves were performed with PCE in the hydrogen stream to understand how PCE affected the system at different potentials. Figure 14 shows the polarization curves with PCE in the hydrogen stream after the poisoning shown in Figure 13. As seen in previous experiments, the cell did not recover 
from poisoning during operation in neat hydrogen. However, the cell would recover after cyclic voltammetry on the anode.

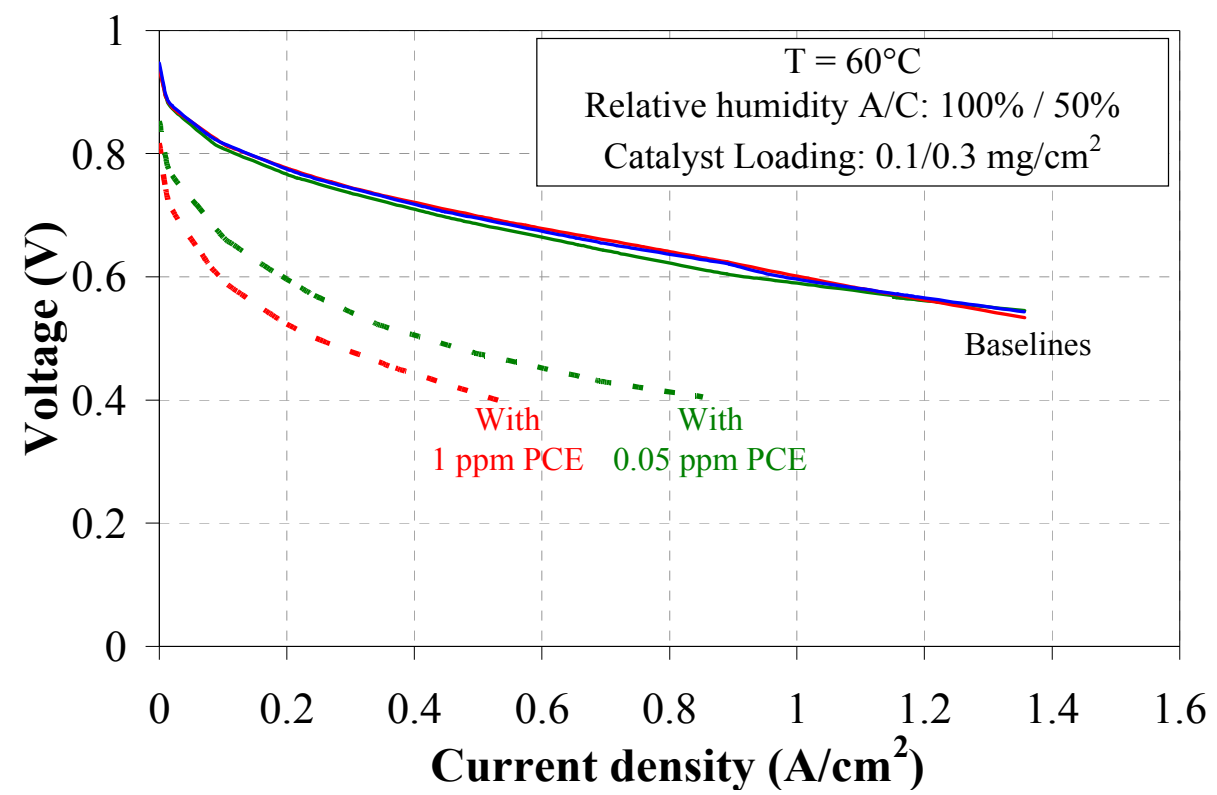

Figure 14. Polarization curves while poisoning with $1 \mathrm{ppm}$ PCE and $0.05 \mathrm{ppm}$ of PCE after steady state saturation has been reached.

\subsection{Effect of Hydrocarbons}

Metal catalysts like Pt are commonly used for reactions of hydrocarbons, and significant experimental and theoretical efforts have been made to study the interactions of small hydrocarbons with metal surfaces. ${ }^{80-83}$ Unfortunately, no systematic work has been carried out examining the influence of trace hydrocarbons on the performance of electrocatalysts of PEMFCs.

Tetrahydrofuran (THF) is being studied as a hydrocarbon model molecule. It was selected due to its wide use as a common solvent for many chemical syntheses. It is widely used for the production of hydrogen storage materials for the solid state storage of hydrogen for fuel cells. In this study, we have tested 3 different concentrations in the hydrogen stream including concentrations at $0.5 \mathrm{ppm}$ which corresponds to the hydrocarbon ISO limit of 2 ppm per carbon basis. While no effects have been observed on the ionic conductivity and during cyclic voltammetry, a large effect on the fuel cell performance was observed as indicated in the potentiostatic curve for a Gore MEA in Figure 15. As it can be observed there is a drop in performance in the range of $42 \%$ to $16 \%$ for concentrations between $5 \mathrm{ppm}$ and $0.5 \mathrm{ppm}$ of THF, respectively. Even at the low concentration of $0.5 \mathrm{ppm}$ the drop occurs fast, reaching steady state in approximately 25 hours. However the short term effects are only temporary since once the impurity is removed the fuel cell performance is recovered. 
SRNL-STI-

Revision 0

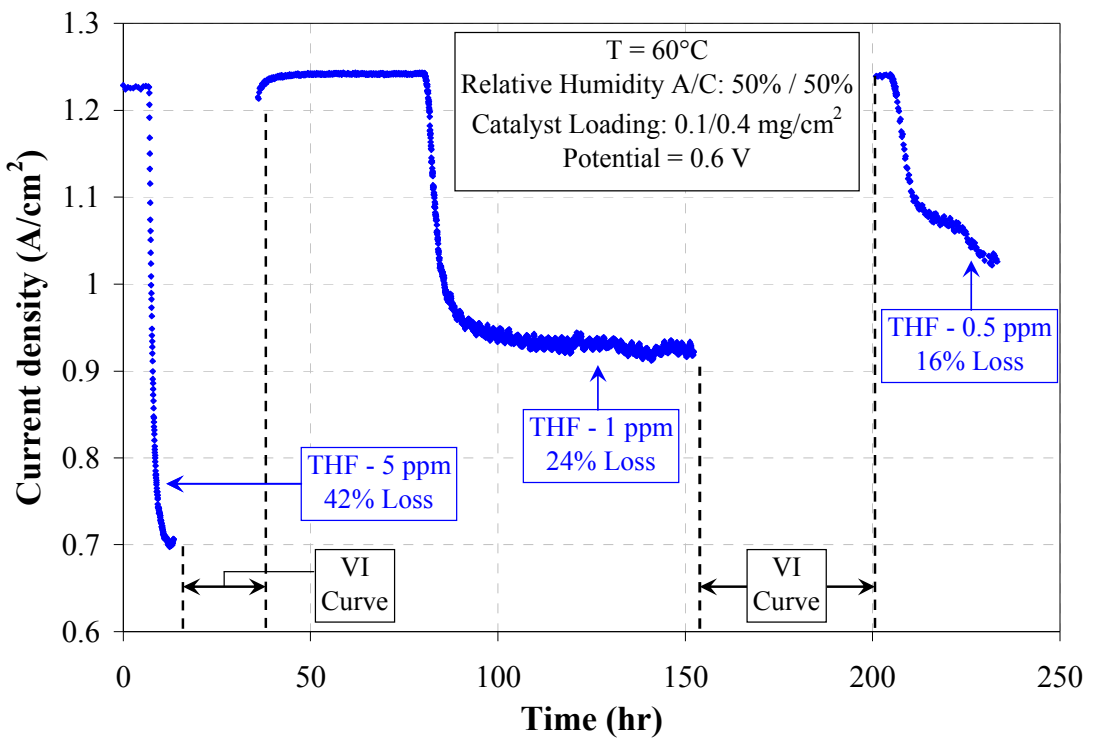

Figure 15. Potentiostatic (0.6 V vs. DHE) current decay and recovery during various concentrations of THF in the hydrogen stream in a $50 \mathrm{~cm}^{2}$ Gore MEA with an anode Pt loading of $0.1 \mathrm{mg} / \mathrm{cm} 2$ at $60{ }^{\circ} \mathrm{C}$ and $50 \% \mathrm{RH}$.

Figure 16 shows the polarization before and during the THF poisoning, and after the recovery. This figure confirms the complete fuel cell recovery once the impurity is removed. Long term fuel cell performance in the presence of THF will be studied in order to investigate if THF polymerizes inside the fuel cell electrodes.

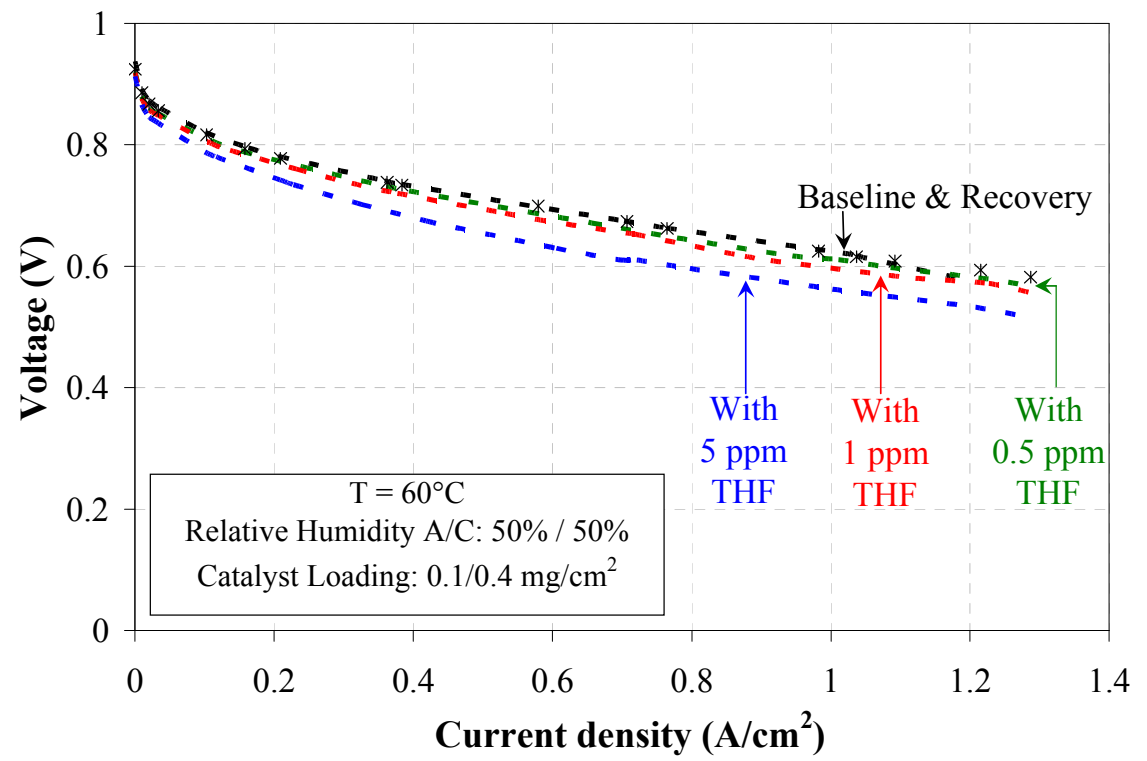

Figure 16. Polarization scan before, during and after recovery of the fuel cell during various concentrations of THF in the hydrogen stream in a $50 \mathrm{~cm}^{2}$ Gore MEA with an anode Pt loading of $0.1 \mathrm{mg} / \mathrm{cm} 2$ at $60^{\circ} \mathrm{C}$ and $50 \% \mathrm{RH}$. 


\subsection{Conclusions}

Runs at ISO proposed concentration levels show that model hydrocarbon compound such as tetrahydrofuran can cause serious degradation. However, the degradation is only temporary as when the impurity is removed from the hydrogen stream the performance completely recovers. This is the first time the effects of THF are documented in the fuel cell research. Other molecules at the ISO concentration levels such as ammonia don't show effects on the fuel cell performance. This result is encouraging, as literature data suggests that concentrations higher than $0.1 \mathrm{ppm}$ can cause serious degradation and shorten the fuel cell life. On the other hand, carbon monoxide and perchloroethylene shows major degradation and the system can only be recovered by following specific recovery procedures.

\subsection{Recommendations, Path Forward or Future Work}

Future work should include the study of the combinatorial effects of multiple impurities on the performance of the fuel cell. It is expected that impurities detrimental effects on performance will be additive, as different impurities affect different reaction sites on the electrocatalysts surface. 


\subsection{References}

(1) EG\&G-Services Fuel Cell Handbook, 5th ed.; Parsons Inc., 2000.

(2) Litster, S., McLean, G. Journal of Power Sources 2004, 130, 61-76.

(3) Wilson, M. S.: U.S.5234777, 1993.

(4) Cha, S. Y.; Lee, W. M. Journal of the Electrochemical Society 1999, 146, 40554060.

(5) O’Hayre, R.; Lee, S. J.; Cha, S. W.; Prinz, F. B. Journal of Power Sources 2002, 109, 483-493.

(6) Veldhuis, J. B. J.; de Bruijn, F. A.; Mallant, R. K. A. M. Proceedings of the Seminar on Fuel Cell 1998.

(7) Um, S. Journal of The Electrochemical Society 2000, 147, 4485-4493.

(8) Gierke, T. D.; Hsu, W. Y. In ACS symposium series 180; Eisenberg, A., Yeager, H. L., Eds.; American Chemical Society: Washington, D.C.,, 1982, pp 283.

(9) Hsu, W. Y.; Gierke, T. D., 13 (1983) 307. Journal of Membrane Science 1983, 13, 307.

(10) Sondheimer, S. J.; N.J., B.; C.A., F. Journal of Macromolecular Science Reviews in Macromolecular Chemistry and Physics 1986, C26, 353.

(11) Heitner-Wirguin, C. Journal of Membrane Science 1996, 120, 1.

(12) Mauritz, K. A.; Moore, R. B. Chemical Reviews 2004, 104, 4535.

(13) Kreuer, K. D. Journal of Membrane Science 2001, 185, 29.

(14) Kreuer, K. D. In Handbook of fuel cells - fundamentals, technology, and applications; Vielstich, W., Lamm , A., Gasteiger, H. A., Eds.; John Wiley and Sons, Ltd.,: Chichester, U.K, 2003.

(15) Lee, S. J.; Mukerjee, S.; Ticianelli, E. A.; McBreen, J. Electrochimica Acta 1999, 44, 3283-3293.

(16) Toda, T.; Igarashi, H.; Uchida, H.; Watanabe, M. Journal of The Electrochemical Society 1999, 146, 3750-3756.

(17) Haile, S. M. Acta Materialia 2003, 51, 5981-6000.

(18) Farrauto, R. J. Applied Catalysis, B: Environmental 2005, 56, 3-7.

(19) Gottesfeld, S.; Zawodzinski, T. A. In Advanced in Electrochemical Science and Engineering; Alkire, R. C., Gerischer, H., Kolb, D. M., Tobias, C. W., Eds.; Wiley-VCH: Weinherm, 1997; Vol. 5.

(20) Gottesfeld, S.; Pafford, J. Journal of The Electrochemical Society 1988, 135, 2651.

(21) Springer, T. E.; Rockward, T.; Zawodzinski, T. A.; Gottesfeld, S. Journal of The Electrochemical Society, 2001, 148, A11-A23.

(22) Zhang, J.; Thampan, T.; Datta, R. Journal of the Electrochemical Society 2002, 149, A765-A772.

(23) Chan, S. H.; Goh, S. K.; Jiang, S. P. Electrochim. Acta 2003, 48, 1905.

(24) Chu, H. S.; Wang, C. P.; Liao, W. C.; Yan, W. M. Journal of Power Sources 2006.

(25) Bhatia, K. K.; Wang, C. Y. Electrochimica Acta 2004, 49, 2333-2341.

(26) Oetjen, H.; Schmidt, V.; Stimming, U.; Trila, F. Journal of The Electrochemical Society 1996, 143, 3838.

(27) Murthy, M.; Esayian, M.; Hobson, A.; MacKenzie, S.; Lee, W.; Van Zee, J. Journal of The Electrochemical Society 2001, 148, A1141.

(28) Wagner, N.; Gülzow, E. Journal of Power Sources 2004, 127, 341-347. 
(29) Stamenkovic, V.; Chou, K. C.; Somorjai, G. A.; Ross, P. N.; Markovic, N. M. Journal of Physical Chemistry B 2005, 109, 678-680.

(30) Mayrhofer, K. J. J.; Arenz, M.; Blizanac, B. B.; Stamenkovic, V.; Ross, P. N.; Markovic, N. M. Electrochimica Acta 2005, 50, 5144-5154.

(31) Arenz, M.; Mayrhofer, K. J. J.; Stamenkovic, V.; Blizanac, B. B.; Tomoyuki, T.; Ross, P. N.; Markovic, N. M. Journal of the American Chemical Society 2005, 127, 6819-6829.

(32) Davies, J. C.; Nielsen, R. M.; Thomsen , L. B.; Chorkendorff , I.; Logadóttir, Á.; Lodziana, Z.; Nørskov , J. K.; Li, W. X.; Hammer, B.; Longwitz, S. R.; Schnadt, J.; Vestergaard, E. K.; Vang, R. T.; Besenbacher, F. Fuel Cells 2004, 4, 309-319.

(33) Villegas, I.; Weaver, M. J. Journal of Chemical Physics 1994, 101, 1648-1660.

(34) Markovic, N. M.; Lucas, C. A.; Grgur, B. N.; Ross, P. N. The Journal of Physical Chemistry B 1999, 103, 9616 -9623.

(35) Rice, C.; Tong, Y.; Oldfield, E.; Wieckowski, A. Electrochimica Acta 1998, 43, 2825-2830.

(36) Tong, Y.; Belrose, C.; Wieckowski, A.; Oldfield, E. 119 1997, Journal of the American Chemical Society, 11709-11710.

(37) Day, J. B.; Vuissoz, P.-A.; Oldfield, E.; Wieckowski, A.; Ansermet, J.-P. Journal of the American Chemical Society 1996, 118, 13046-13050.

(38) Han, K. S.; Han, O. H. Electrochimica Acta 2001, 47, 519-523.

(39) Kim, J.-D.; Park, Y.-I.; Kobayashi, K.; Nagai, M. Journal of Power Sources 2001, 103, 127.

(40) Ciureanu, M.; Wang, H. J. New Mater. Electrochem. Syst. 2000, 3, 107.

(41) Stonehart, P.; Ross, P. N. J. Catal. Rev. Sci. Eng. 1975, 12, 1.

(42) Kim, J.-D.; Park, Y.-I.; Kobayashi, K.; Nagai, M.; Kunimatsu, M. Solid State Ionics 2001, 140, 313.

(43) Adams, W. A.; Blair, J.; Bullock, K. R.; Gardner, C. L. Journal of Power Sources 2005, 145, 55-61.

(44) Papageorgopoulos, D. C.; de Bruijn, F. A. Journal of The Electrochemical Society 2002, 149, 140-145.

(45) Wilson, M. S.; Derouin, C.; Valerio, J.; Zawodzinski, T. A.; Gottesfeld, S. Electrocatalysis, 1993; 1.1203-1201.1208.

(46) Gottesfeld, S.; Pafford, J. Journal of The Electrochemical Society 1998, 135, 2651-2652.

(47) Bellows, R. J.; Marucchi-Soos, E.; Reynolds, R. P. Electrochem. Solid State 1998, 1, 69-70.

(48) Schmidt, V. M.; Oetjen, H.-F.; Divisek, J. Journal of The Electrochemical Society 1997, 144, 237-238.

(49) Grgur, B. N.; Zhuang, G.; Markovic, N. M.; Ross, P. N. The Journal of Physical Chemistry B 1997, 101, 3910-3913.

(50) Gasteiger, H. A.; Markovic, N.; Ross, P. N. J. Journal of Physical Chemistry 1994, 98, 617-625.

(51) Gasteiger, H. A.; Markovic, N. M.; Ross, P. N. J. Journal of Physical Chemistry 1995, 99, 8290-8301.

(52) Ley, K. L.; Liu, R.; Pu, C.; Fan, Q.; Leyarovska, N.; Segree, C.; Smotkin, E. S. Journal of The Electrochemical Society 1997, 144, 1543-1548. 
(53) Napporn, W. T.; Leger, J.-M.; Lamy, C. Journal of The Electrochemical Society 1996, 408, 141-147.

(54) Mukerjee, S.; Srinivasan, S. Journal of The Electrochemical Society 1993, 357, 201-224.

(55) Mukerjee, S.; Srinivasan, S.; Soriaga, M. P. Journal of The Electrochemical Society 1995, 142, 1409-1422.

(56) Chen, K. Y.; Shen, P. K.; Tseung, A. C. C. Journal of The Electrochemical Society 1995, 142, 185-186.

(57) Iorio, T.; Yasuda, K.; Siroma, Z.; Fujiwara, N.; Miyazaki, Y. Journal of The Electrochemical Society 2003, 150, 1225-1230.

(58) Wee, J.-H.; Lee, K.-Y. Journal of Power Sources 2005, ASAP.

(59) Gland, J. L.; Kollin, E. B. Journal of Vaccum Science and Technology 1981, 18, 604-606.

(60) Ostermaier, J. J.; Katzer, J. R.; Manogue, W. H. Journal of Catalysis 1974, 33, 457-473.

(61) Szulczewski, G.; Levis, R. J. J. Chem. Phys. 1994, 101, 11070-11073.

(62) Gland, J. L.; Kollin, E. B. Surface Science 1981, 104, 478-490.

(63) Baetzold, R. C.; Apai, G.; Shustoroich, E. Applications of Surface Science 1984, $19,135-144$.

(64) Illas, F.; Lopez, N.; Garcia-Hernandez, M.; Moreira, I. d. P. R. Journal of Molecular Structure 1999, 458, 93-98.

(65) Garcia-Hernandez, M.; Lopez, N.; Moreira, I. d. P. R.; Paniagua, J. C.; llas, F. Surface Science 1999, 430.

(66) Amorelli, T. S.; Carley, A. F.; Rajumon, M. K.; Roberts, M. W.; Wells, P. B. Surface Science 1994, 315, L990-L994.

(67) Chellappa, A. S.; Fische, C. M.; Thomson, W. J. Applied Catalysis A: General 2002, 227, 231-240.

(68) Uribe, F. A.; Gottesfeld, S.; T A Zawodzinski, J. J. Electrochem. Soc. 2002, 149, A293-A296.

(69) Soto, H. J.; Lee, W.-K.; Zee, J. W. V.; Murthy, M. Electrochem. Solid-State Lett. 2003, 6, A133.

(70) Halseid, R.; Vie, P. J. S.; Tunold, R. Journal of Power Sources 2005, ASAP.

(71) Wagner, F. T.; Moylan, T. E. Surface Science 1989, 216, 361-385.

(72) Kashima, K.; Umeda, M.; Yamada, A. Bunseki Kagaku 2004, 53, 1055-1059.

(73) Pell, W. G.; Zolfaghari, A.; Conway, B. E. J. Electroanal. Chem. 2002, 532, 13.

(74) Novak, D. M.; Conway, B. E. J. Chem. Soc. Faraday Trans 1981, 177, 2341.

(75) Zolfaghari, A.; Conway, B. E.; Jerkiewicz, G. Electrochim. Acta 2002, 47, 1173.

(76) Conway, B. E.; Zolfaghari, A.; Pell, W. G.; Jerkiewicz, G. Electrochimica Acta 2003, 48, 3775-3778.

(77) Strmcnik, D.; Gaberscek, M.; Hocevar, S.; Jamnik, J. Solid State Ionics 2005, 176, $1759-1763$.

(78) Ernst, S.; Herber, R.; Slavcheva, E.; Vogel, I.; Baltruschat, H. Electroanalysis 2001, 13, 1191-1197.

(79) Oelgeklaus, R.; Baltruschat, H. Sensors and Actuators, B: Chemical 1997, B42, 31-37. 
(80) Masel, R. I. Principles of Adsorption and Reaction on Solid Surfaces; Wiley: New York, 1996.

(81) Somorjai, G. A. Introduction to Surface Chemistry and Catalysis; Wiley: New York, 1994.

(82) van Santen, R. A.; Neurock, M. Catal. Rev. Sci. Eng. 1995, 37, 557.

(83) Neurock, M. Appl. Catal. A: General 1997, 160, 169. 